\title{
Potential Use of Kilibwoni Bubbling Spring Water, Nandi County, Kenya
}

\author{
Wanyoike Muchiri ${ }^{1}$, Ng'etich Job Kipkurgat ${ }^{2}$, Munyao Thomas ${ }^{2}$, Lutta Samuel ${ }^{1}$, \\ Kiplagat Andrew ${ }^{2}$, Kudenyo Chibole ${ }^{2}$ \\ ${ }^{1}$ School of Science, University of Eldoret, Eldoret, Kenya \\ ${ }^{2}$ School of Environmental Studies, University of Eldoret, Eldoret, Kenya
}

Email address:

ngetichjob@yahoo.com (J.K. Ng'etich)

\section{To cite this article:}

Wanyoike Muchiri, Ng'etich Job Kipkurgat, Munyao Thomas, Lutta Samuel, Kiplagat Andrew, Kudenyo Chibole. Potential Use of Kilibwoni Bubbling Spring Water, Nandi County, Kenya. Journal of Water Resources and Ocean Science. Vol. 10, No. 4, 2021 , pp. 68-77. doi: 10.11648/j.wros.20211004.11

Received: April 1, 2021; Accepted: June 11, 2021; Published: July 21, 2021

\begin{abstract}
The demand for carbonated water in Kenya is in the rise, owing to increasing lifestyle diseases like obesity, which requires that to reduce weight and remain healthy; a lot of carbonated water should be taken throughout the day. This research was set to determine the potetntial use of Kilibwoni bubbling springs in Nandi County, Kenya. Six sampling points were identified; three bubbling points labeled as (P1, P2, and P4), a shallow well (P3), river (P5), and a spring (P6). A total of 60 samples were collected during the dry and rainy seasons. The samples were selected cations and anions, indicator bacteria, carbonation and physio-chemical properties. Spectrophotometry (HACH DR6000) was used to determine the concentrations of Nitrates, Phosphates, iron, manganese, Flame photometry was used for sodium and potassium determination, argentometric method for chloride, membrane filtration was used to determine total and feacal coliforms, dissolved carbon dioxide was determined using a carbonation meter (CarboQC). The water temperature, electrical conductivity, total dissolved solids (TDS) were measured in situ, using portable pre-calibrated HANNA waterproof Tester pH, TDS, Temperature, and Electrical Conductivity Meter (model HI 98129), complexiometric titration was used to establish the total hardness in the water. Results: The water was contaminated with feacal and total coliforms in all the sampling points P1, P2, P3, P4, P5, and P6. High turbidity was recorded in sampling points P1, P2, P4, high amounts of iron and manganese above those recommended by WHO and KEBS for drinking water were recorded in most sampling points. The water recorded low $\mathrm{pH}$ values in both seasons for all but P5 sampling points with 6.8 and 6.37 in the rainy and dry seasons. The pH values for the other samples ranged between $3.41-4.93$ in the rainy season and 3.8-5.25 in the dry season. The dissolved $\mathrm{CO}_{2}$ concentration of the water ranged from $1.20 \mathrm{~g} / \mathrm{L}$ to $2.65 \mathrm{~g} / \mathrm{L}$ in the rainy season and $1.50 \mathrm{~g} / \mathrm{L}$ to $3.00 \mathrm{~g} / \mathrm{L}$ in the dry season for all sampling points but P5 recorded $\mathrm{CO}_{2}$ values of 0.5 and $0.4 \mathrm{~g} / \mathrm{L}$ for rainy and dry season respectively. The results showed the water from all the sampling points except P5, contained sufficient dissolved carbon dioxide for use as natural carbonated water. However, purification and treatment is necessary to lower the turbidity of the water, eliminate the microbial contaminants and adjust $\mathrm{pH}$ to at least 4 , to conform to the KEBS recommendation for naturally carbonated water.
\end{abstract}

Keywords: Natural Carbonated Mineral Water, Bubbling Spring Water, Lifestyle Diseases

\section{Introduction}

Water is life and it is a scarce resource which requires sound planning and conservation. The WHO standards require that at least 50 litres of water should be consumed per person per day. However this target is not met because water is scarce. Globally $97.5 \%$ of water is salty while a paltry $2.5 \%$ of water is fresh water and therefore available for use by humanity [4]. These underscore the need to explore the potential for utilization of ground water which the proposed study on the potential for carbonated water in Kilibwoni area in Nandi County attempted to do. There 
exists an underground water fissure, a water fountain, with unceasing water flow, which has been used by the local community over the generations for watering their livestock and for domestic use because of the water quality water component. The study involved analysis of chemical quality parameters of water and to recommend ways and means through which water from Kilibwoni spring can be used to generate carbonated water. It also gives an indication on the process within which water from the spring can be treated in order to attain tolerable carbonated water level.

\subsection{Statement of the Problem}

The demand for water is on the increasing trend and it is becoming a scarce commodity owing to the burgeoning population. The use of Mineral water has been in Kenya for over a decade now and the demand for carbonated water is equally gaining momentum. Consumption of carbonated water in Europe is higher than in developing countries including Kenya. Carbonated water is artificially prepared by introducing carbon dioxide in water to dissolve carbonic acid in the water. Carbonated water provides alternatives to health living as people stay hydrated throughout the day. Among the companies that produce Mineral water in Kenya it is only Kiringet that has its supply as seen in various Supermarkets in Kenya. The study is set to explored whether Kilibwoni bubbling spring water which occur naturally in Kilibwoni area in Nandi county can be used to generate carbonated water which if utilized can contribute towards meeting the ever increasing demand for carbonated water in Kenya, resulting in better health living. There is paucity of data and literature on, carbonated water in terms of how it is prepared, its use and importance and therefore this study contributes towards building on a body of knowledge on innovation of carbonated water in Kenya. More specifically knowledge on potability of Kilibwoni bubbling spring water in Nandi County is missing, and hence the need for this study. As Zimmerman puts it, "something becomes a resource if it is useful to humanity", [15]. The natural bubbling spring water from Kilibwoni is known locally by the community as" Soda water" (Sugutek) and is used for drinking occasionally especially in dealing with" hangover" conditions by some people and for use by livestock as alternative to salt for animals [7]. However no study has ever been done to establish these facts. The study endeavored to discover how carbonated water can be harnessed from Kilibwoni bubbling spring water in Nandi County, Kenya, and which has the potential for patenting. Kilibwoni bubbling spring water, if harnessed based on the study findings will have a rejuvenating effect on the socioeconomy of the local community and beyond including; healthy living as it is to be used for domestic use, creation of jobs and skills development in resource use and revenue generation to Nandi County and to the local community, that is if this study is later implemented as a project. The proposed research site is remote and unknown and the site was mapped out using G PS and its value and importance is worth determining.

\subsection{Objectives of the Study}

The study was done within the purview of the following objectives;

To determine the chemical Composition of Kilibwoni bubbling Spring Water

To determine the potential use of Kilibwoni bubbling Spring Water

The guiding research questions were;

1. What is the chemical content of Kilibwoni bubbling Spring Water?

2. What is the potential yield of Kilibwoni bubbling Spring Water?

3. How can Kilibwoni bubbling Spring Water be used?

Justification and Significance of Study

The study was set to explore whether Kilibwoni bubbling spring water in Nandi county can be used to generate carbonated water which if utilized can contribute towards meeting the ever-increasing demand for carbonated water in Kenya, resulting in better health living. Knowledge on, carbonated water in terms of how it is prepared, its use and importance is missing therefore this study contributes towards filling this gap on carbonated water in Kenya. The study contributes on how carbonated water can be harnessed from Kilibwoni bubbling spring water Nandi County, Kenya, and which has the potential for patenting. Kilibwoni bubbling spring water, if harnessed based on the study findings will have a ripple effect on the socio-economy of the local community including; healthy living as it is to be used for domestic use, employment creation and skills development and transfer in the area of resource use, and revenue generation to Nandi County and to the local community.

\section{Theoretical Literature}

Carbonated water, which is also christened seltzer water, sparkling water, or soda water, is essentially water in which carbon (IV) oxide has dissolved. Carbon (IV) oxide can be pumped into and dissolved in water artificially, making carbonated water. Carbonated water as well occurs naturally, owing to specific geological processes [9]. Artificially made carbonated water was first 'invented' in the mid 1700s in the United Kingdom, by Priestley Joseph. In his experiment Priestley suspended water over a vat of fermenting beer, producing carbon IV oxide, which passively dissolved in water forming carbonated or sparkling water. Today carbonated drinks are popular and day to day beverages. They are a staple of the modern cookery repertoire, ranging from sparkling water to beer, soda water, soda pop to name but a few.

Owing to the health risk associated with sugary drinks like sodas, pure carbonated water has gained a lot of popularity of late. As a matter of fact, CBS estimates that sales of sparkling water in 2018 hit an all times high of $\$ 2.2$ billion, Wired on the other hand postulated that the sales of La Croix one of the popular brands of soda water, had more than 
tripled in the last couple of year. In addition statistica.com estimates that this industry will be valued at over six billion US dollar come the year 2021 [10].

\subsection{Health Benefits of Carbonated Water}

Studies have elaborated the benefits of carbonated water and how it improves the entire digestive system. These includes the fact that carbonated water helps in improving swallowing ability, increases the feeling of fullness and lastly it aids in relieving constipation. According to Morishita at el, 2014, carbonated water aided in chemical as well as gustatory stimulations of the pharyngeal mucosa and the oral cavity resulting in improved pharyngeal swallowing. Michou et al, 2012 [6] examined the role of soda water and temperature on swallowing performance for patients with dysphagia, concluding that chemothermal stimulation with carbonated water were very effective in modulating swallowing. On the other hand carbonated water has been advocated to relieve dyspeptic symptoms as it alters gastric motility through gastric distension. Overall, sparkling water improves the digestive symptoms, relieves constipation and advances gallbladder emptying.

Naturally carbonated water keeps one feeling satiated for long - having sources of naturally carbonated water that are not exploited means lost opportunities for making people feel satiated for long, improving their dietary intake [14]. If one feels full for extended periods, he or she is likely to adopt a healthy eating lifestyle.

Studies have illustrated that sodium rich carbonated water helps in curbing heart related diseases by lowering the LDLcholesterol and increasing the HDL cholesterol, in addition it has as well been demonstrated that taking carbonated water rich in sodium can reduce fasting serum glucose concentrations by up to $6.7 \%$ [8], [13]. Consumption of sodium rich carbonated water thus plays a major role in prevention of cardiovascular diseases and the metabolic syndrome.

\subsection{Carbonated Water and Oil Recovery}

Over the last about three decades many companies in the oil industry have used carbon dioxide for oil recovery. $\mathrm{CO}_{2}$ injection for oil recovery in mature fields is perhaps one of the most popular methods over conventional water injection method [2]. The major advantage of $\mathrm{CO}_{2}$ is that at reservoir conditions $\mathrm{CO}_{2}$ acts as a supercritical fluid, which readily develops miscibility with the oil. And as such in reservoirs where miscibility is unachievable, $\mathrm{CO}_{2}$ injection leads to additional oil recovery by favorably modifying the oil flow properties. However, $\mathrm{CO}_{2}$ injection as a method suffers two major drawbacks; gravity segregation and poor sweep efficiency.

To overcome these problems, carbonated water injection (CWI), is proving to be a superior alternative. Carbonated water injection is not a new technique; it was conceptualized in the 1930s, and by the beginning of 1970 s serious investigations on the same had began. Carbonated water has lesser difference with crude oil density and viscosity compared to supercritical $\mathrm{CO}_{2}$, and as such has better sweep efficiency. In addition, CWI works better in reservoirs that have been water flooded, as it minimizes the drawbacks of water shielding due to mixing with resident water; in this case $\mathrm{CO}_{2}$ injection will not be favorably due to longer $\mathrm{CO}_{2}$ diffusion time resulting in poor gravity segregation and low sweep efficiency.

There are two major differences between CWI and direct $\mathrm{CO}_{2}$ injection or water alternating $\mathrm{CO}_{2}$ gas injection. First, the $\mathrm{CO}_{2}$ amount that can be injected into the reservoir at a given temperature and pressure will be limited by solubility, implying lack of a separate $\mathrm{CO}_{2}$ rich phase in the reservoir. Secondly, the minimum miscibility pressure (MMP) does not determine the displacement efficiency. Rather, the displacement efficiency is controlled by $\mathrm{CO}_{2}$ mass transfer between oil and $\mathrm{CW}$. This leads to no-transition zone in the CW (Dong et al, 2011)

In this study the team undertook an analysis of water from Kiplolok, kilibwoni bubbling springs in Nandi County, Kenya. The springs are on a three acre piece of land in Kipkolok village, Kilibwoni ward, Emgwen sub-county, Nandi County. It comprises of several natural holes that have pulping salty lime water. According to the local community this water tastes like, sprite soda or tonic water, alluding to the fact that the pulping of the water maybe as a result of high pressure of dissolved gases emanating from geological activities and processes. In addition the community, claimed that this water has some medicinal value; relieves discomforts associated with digestion, and relieved hangover. It is under this background that it was necessary to determine the quality of the water, for use as carbonated water. The results from the analysis were compared with the standards set by the World Health Organisation (WHO) and Kenya Bureau of Standards (KEBS), for drinking water and 2009/54/EC Directive for naturally carbonated water.

\section{Materials and Methods}

All the reagents used in this study were of analytical grade. The analytical methods used in this study included UV-Vis Spectroscopy (using DR6000 HACH Spectrometer), Volumetric method (Mohr's Method), Complexometric titration, CarboQC Anton Paar GmbH carbonation meter and HANNA waterproof Tester $\mathrm{pH}$, TDS, Temperature and Electrical Conductivity Meter (model HI 98129).

\subsection{Sampling}

This study used purposive sampling method. Six major sampling points, from which the resident draw water were identified and sampled. These sampling points included; three bubbling points, one shallow well, river, and spring. Sampling was done twice; during the rainy season, and during the dry season. Figure 1 and Figure 2 shows sampling water points and an image of existing bubbling spring water point. 


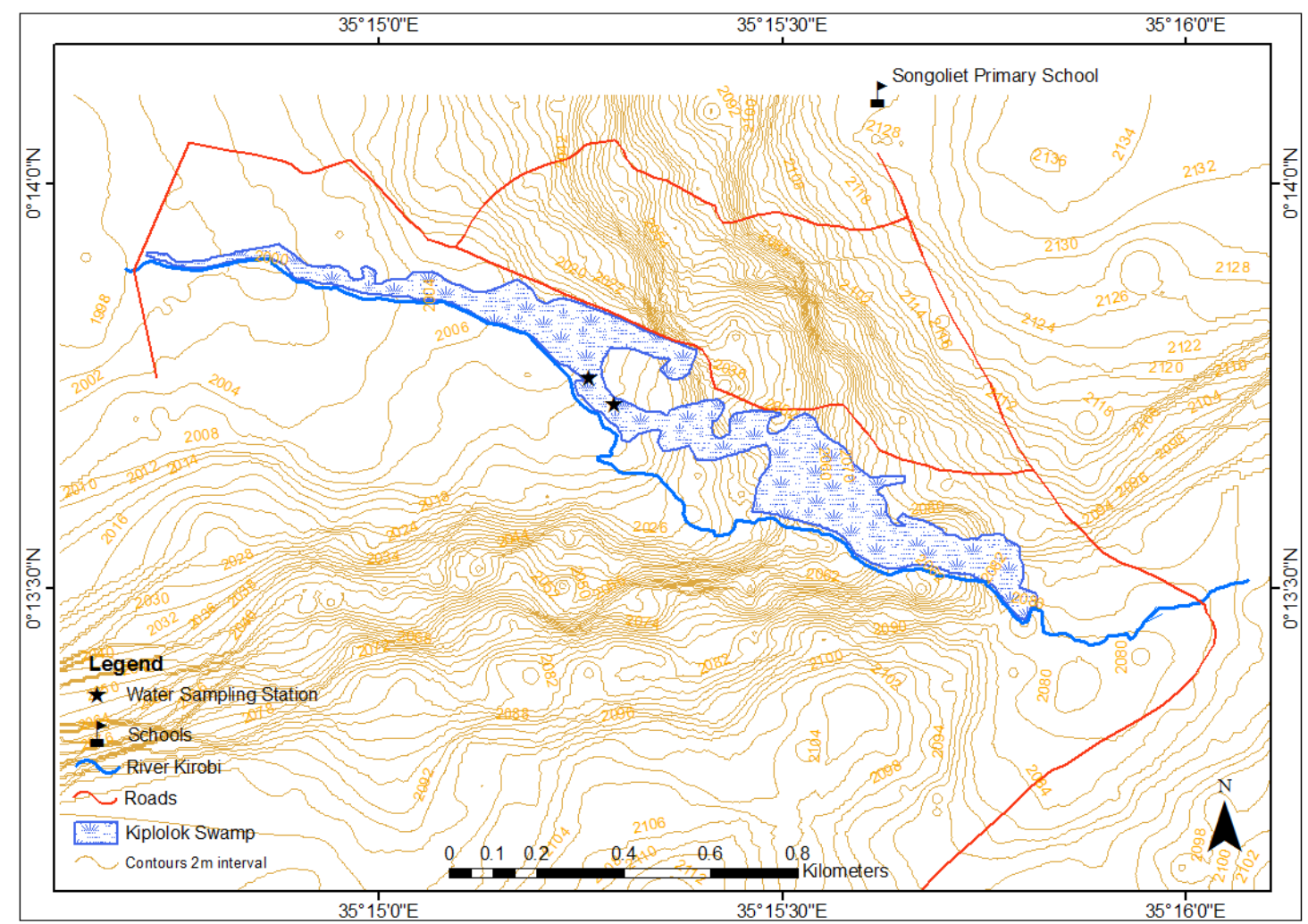

Figure 1. Shows the site where samples of bubbling spring water were obtained.

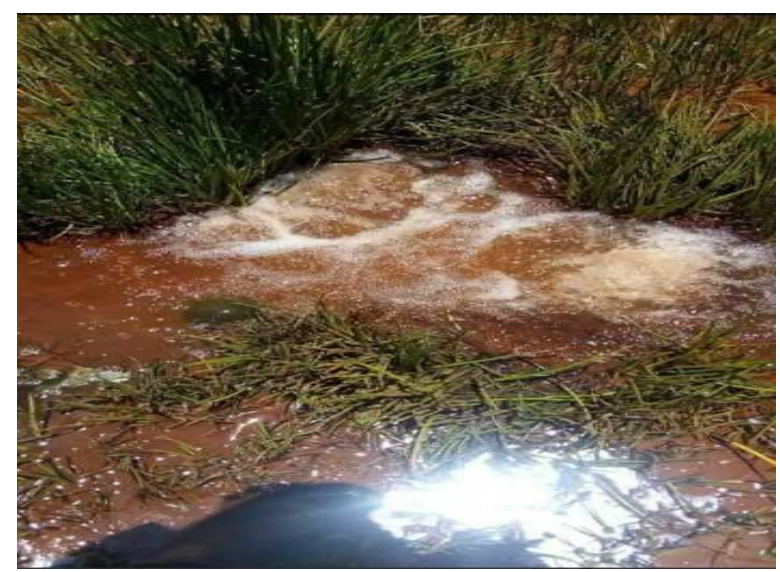

Figure 2. Shows an existing bubbling spring water point in Kiplolok site.

Water samples were taken from six bubbling spring water points for, physiochemical analysis, sodium and potassium determination, microbial analysis and for carbonation. The sampling containers were then properly labelled for easier identification and recording purposes. At each sampling point, sampling containers (cleaned and rinsed with distilled water) were rinsed twice with the sample water prior to sample collection. Nitric acid was added to samples collected for chemical analysis for preservation purposes. The water temperature, electrical conductivity, total dissolved solids (TDS), were measured in situ, using portable pre-calibrated HANNA waterproof Tester $\mathrm{pH}$, TDS, Temperature and Electrical Conductivity Meter (model HI 98129), as soon as the samples are collected. The samples were then transported to the Eldoret Water and Sanitation (ELDOWAS) laboratory for physio-chemical and microbial analysis, Kenya bureau of Standards (KEBS) laboratory for carbonation and to University of Eldoret (UoE) Chemistry Laboratory for sodium and potassium analysis. The samples were refrigerated at temperature $4^{\circ} \mathrm{C}$ awaiting analysis. For microbial analysis the samples were collected in $500 \mathrm{~mL}$ sterilized Schott Duran Bottles, the bottles were thoroughly sterilized prior to sample collection. The samples were then be kept in ice box and transported to laboratories for analysis within three hours to minimize microbes' growth.

\subsection{Laboratory Analysis}

\subsubsection{Determination of Dissolved Carbon Dioxide}

Dissolved carbon dioxide was determined using CarboQC Anton Paar GmbH carbonation meter. CarboQC is a relatively small equipment weighing not more than $3.1 \mathrm{~kg}$ and measuring about $190 * 120 * 305 \mathrm{~mm}$. It is used to measure pressurized carbon dioxide in liquids. The measuring chamber was filled with $10 \mathrm{~mL}$ of the sample to be determined. The chamber was then sealed and the volume inside expanded twice by use of a motor driven piston with an attached stirrer. The equilibrium pressure and temperature at every expansion step were determined and based on the difference in relative solubilities of dissolved carbon dioxide and the air based in aqueous solution their net contribution was estimated. The calculated results were then displayed in about a minute and a half showing the amount of dissolved $\mathrm{CO}_{2}$ in $\mathrm{g} / \mathrm{L}$. 
Standard analytical methods used to determine different physio-chemical parameters included Mohr Method is for determination of chloride, Ethylenediamine Tetraacetic Acid (EDTA) titrimetric method for total hardness, Sodium and potassium were analyzed by flame photometer. Fecal and total coliforms were determined using membrane filtration.

\subsubsection{Determination of Nitrate}

The concentration of nitrate ions in the water samples were determined using spectrophotometry -DR6000 model using cadmium reduction method. For water samples with high turbidity filtration using 0.45 micron filter paper was done prior to the actual analysis. $5 \mathrm{~N}$ sodium hydroxide solution was added to water samples to adjust the $\mathrm{pH}$ to around 7 prior to starting the analysis. The DR6000 spectrophotometer was set, by selecting the appropriate program (355 N, Nitrate HR PP), please note that this uses $500 \mathrm{~nm}$ wavelength. 10 $\mathrm{mL}$ of the sample water put into a sample cell, one NitraVer 5 nitrate reagent powder pillow added into the sample. This was then left standing for a 1-minute reaction time, before putting the stopper on the sample cell and shaking the content to allow the undissolved powder to dissolve. A further 5minute reaction time was set, until an amber color appeared indicating the presence on nitrate. A blank of deionized water was put in a different cell sample and used to zero the instrument, before the sample was inserted into the instrument and the reading indicating the nitrate concentration taken.

\subsubsection{Determination of Phosphate}

The concentration of Phosphate ions in the water samples were determined using spectrophotometry -DR6000 model using Acid Persulfate digestion method. $5 \mathrm{~N}$ sodium hydroxide solution was added to water samples to adjust the $\mathrm{pH}$ to around 7 prior to starting the analysis. The DR6000 spectrophotometer was set, by selecting the appropriate program (536 $\mathrm{P}$, Total/AH PV TNT), please note that this uses $880 \mathrm{~nm}$ wavelength and preheated to $150^{\circ} \mathrm{C} .5 \mathrm{~mL}$ of the sample was added to total Phosphorus Test vial and the contents of one potassium Persulfate powder pillow added. The vial was then capped and the mixture shaken vigorously to dissolve the powder. The vial was put into the reactor and allowed 30 minutes reaction time. On expiry of the 30 minutes reaction time, the vial was inserted into $16-\mathrm{mm}$ cell holder. And the instrument reading set to zero $(0.00 \mathrm{mg} / \mathrm{L}$ $\mathrm{PO}_{4}{ }^{3-}$ ). PhosVer 3 powder pillow to the vial, capped and shaken for 20-30 seconds to allow proper mixing, and a 2 minute reaction time allowed. The sample was then measured within 8 minute after the 2 minute reaction time expired. The reading was then taken and recorded in $\mathrm{mg} / \mathrm{L} \mathrm{PO}_{4}{ }^{3-}$.

\subsubsection{Determination of Manganese}

The concentration of manganese ions in the water samples was determined using spectrophotometry -DR6000 model using periodate oxidation method. $5 \mathrm{~N}$ sodium hydroxide standard solution to raise the $\mathrm{pH}$ to 4-5. Program 295 manganese was chosen, the sample cell was filled with 10 $\mathrm{mL}$ of the water sample. Content of one buffer powder Pilow, citrate type was added. The content was then thoroughly mixed. Content of sodium periodate was added to the sample cell, and inverted to mix thoroughly. A violet color appeared indicating the presence of manganese. A 2 minute reaction time was allowed. A blank sample cell was then used to calibrate the instrument. The sample cell was then inserted into the instrument and the reading recording in $\mathrm{mg} / \mathrm{L} \mathrm{Mn}$.

\subsubsection{Determination of Total Iron}

The concentration of total iron in water samples was done by using spectrophotometry method (Hach DR6000 spectrophotometer model was used.) Hach Method 8008 was used. Before the analysis samples that a $\mathrm{pH}$ of below 3-5 were adjusted to this range using $5 \mathrm{~N}$ sodium Hydroxide solution. The appropriate program for analysis of total iron using Hach method 8008 was selected, (265 Iron, FerroVer program) on the instrument, the analyzing is done at $510 \mathrm{~nm}$. $10 \mathrm{~mL}$ of the sample was measured into $10 \mathrm{~mL}$ sample cell. The contents of one FerroVer Iron reagent powder pillow (a solution of thioglycolic acid and ammonia) and were added into the sample cell. Mixing of the sample was done by swirling the sample cell. The mixed content was given a 3 minute reaction time. Calibration of the instrument was done by inserting a blank cell holder into the instrument and setting the instrument at zero reading. The sample cell with the sample was then measured and the reading recorded.

\subsubsection{Determination of Total Coliforms by Membrane Filtration}

A $100 \mathrm{~mL}$ of sample water was filtered through $47 \mathrm{~mm}$, $0.45 \mu \mathrm{m}$ pore size cellulose ester membrane filter, which retained the bacteria in the water sample. The filter was then placed on a 5-mL plate containing MI agar and the plate was then incubated at $35^{\circ} \mathrm{C}$ for 24 hours.

\section{Results and Discussion}

The study was carried out in Kiplolok, Kilibwoni in Nandi County, Kenya. The geographical location and the gprs coordinates for the sampling points are shown in table 1. Samples were collected and analyzed for dry and wet seasons. Carbonation, chemical, microbial and physical properties of the sampled were analyzed.

Analytes concentrations for each parameter were compared with the WHO, KEBS and some with the European parliament Directive 2009/54/EC on mineral water [3]. Parameters with higher values than the standards set by KEBS and WHO drinking water were shown in red in each and every table while $\mathrm{pH}$ that were lower than those accepted by the KEBS and the WHO were shown in yellow color. Importantly to note is that KEBS and 2009/54/EC recommend a $\mathrm{pH}$ minimum value of 4 for carbonated water.

\subsection{Physio-Chemical Parameters}

\subsection{1. $\mathrm{PH}$}

The $\mathrm{pH}$ values ranged from 3.41 at point 1 to 6.37 at sampling point 5 , as shown in the table 1 and figure 1 . The 
$\mathrm{pH}$ levels were below the permitted ranges of 6.5 and 8.5 by the WHO. As such the all the $\mathrm{pH}$ values of were considered acidic and not within the ranges for set by WHO and KEBS for drinking water.. The low $\mathrm{pH}$ values especially from the bubbling points the hand-dug well and the spring can be attributed to geological activities occurring underground, leading to release of carbon dioxide gas that reacts with water forming weak carbonic acid. In the rainy season the $\mathrm{pH}$ ranged from 3.8 in $\mathrm{P} 1$ to 6.8 in point $\mathrm{P} 5$. The $\mathrm{pH}$ showed an inverse correlation with the amount of dissolved $\mathrm{CO}_{2}$. Meaning that the more acidic the water was the higher the concentration of $\mathrm{CO}_{2}$ was in that water.

\subsubsection{Turbidity}

Turbidity can be defined as the clarity of a liquid. Other defines it as the cloudiness or haziness of water. It is a key indicator of water quality and plays a great role in determining the cleanness of water. Most of the sampled points recorded higher values of turbidity above the WHO and KEBS guidelines. The three bubbling points recorded as high as 224 and 320 NTU in P4, 117 and 130 NTU in P1, 261 and 290 NTU P2 during the dry and rainy season respectively. Sampling P5 (sample collected from the river) also recorded values of 39.6 and 50 NTU during the dry and rainy seasons respectively, values that were above the WHO and the KEBS guidelines. Samples drawn from the hand dug well P3 and those from the spring P6 both conformed to the WHO and KEBS standards of $<5$ NTU. These point recorded NTU values of 3.2 and 2.9 in P3 and 3.3 and 4.7 in P6 during the dry season and rainy season respectively. The turbidity values were higher during the rainy season than during the dry season, this could be attributed to transportation of suspended matter into the sampling point by the rain runoff water. The high turbidity on the river could be attributed to the fact that the river swept suspended particles as it flew downstream. The high turbidity values recorded in the bubbling points $\mathrm{P} 1, \mathrm{P} 2$ and $\mathrm{P} 4$ was as the bubbling process dislodging soil particles and given the fact that these points were located in a swampy area with a lot of suspended matter.

\subsubsection{Electrical Conductivity}

The electrical conductivity ranged from $51 \mu \mathrm{S} / \mathrm{cm}$ in $\mathrm{P} 6$ to $156 \mu \mathrm{S} / \mathrm{cm}$ in P5 during the dry season and $55 \mu \mathrm{S} / \mathrm{cm}$ to 139 $\mu \mathrm{S} / \mathrm{cm}$ in P6 and P5 respectively during the rainy season. All the sampled were within the limit set by WHO of $700 \mu \mathrm{S} / \mathrm{cm}$ for drinking and potable water. In addition, electrical conductivity showed a positive correlation with total dissolved solids.

\subsubsection{Total Dissolved Solids and Temperature}

The TDS values ranged from $25 \mathrm{mg} / \mathrm{L}$ in $\mathrm{P} 6$ to $78 \mathrm{mg} / \mathrm{L}$ in P5 during the dry season, while during the rainy season TDS values of between $24 \mathrm{mg} / \mathrm{L}$ and $89 \mathrm{mg} / \mathrm{L}$ in $\mathrm{P} 2$ and $\mathrm{P} 5$ respectively. The values were within the set limits by WHO of $1500 \mathrm{mg} / \mathrm{L}$. The values of TDS directly correlated with electrical conductivity.

Temperature values between 19 and 20.7 in P4 and P6 respectively during the dry season and 15.7 to 16.6 in P2 and P6 respectively during the rainy season. In general lower temperatures were recorded during the rainy season.

\subsubsection{Dissolved $\mathrm{CO}_{2}$}

Dissolved $\mathrm{CO}_{2}$ ranged from $0.40 \mathrm{~g} / \mathrm{L}$ in $\mathrm{P} 5$ to $2.65 \mathrm{~g} / \mathrm{L}$ in $\mathrm{P} 1$ during the rainy season. Consequently, the same trend was observed in the dry season, although the relatively higher concentrations were reported during this season ranging from $0.60 \mathrm{~g} / \mathrm{L}$ in $\mathrm{P} 5$ to $3.00 \mathrm{~g} / \mathrm{L}$ in $\mathrm{P} 1$. These waters could therefore be classified as carbonated based on the European Directive 2009/54/EC [3] and 2003/40/EC that puts the minimum concentration of carbonated water at $1.0 \mathrm{~g} / \mathrm{L}$. However, water sample from P5 (river) does not meet the concentration requirement for carbonated water. Additionally, the concentration of dissolved carbon dioxide seemed to have an inverse correlation with $\mathrm{pH}$ values.

Rainy season

Table 1. Results of Turbidity, $\mathrm{pH}$, Dissolved $\mathrm{CO}_{2}$, Temperature, conductivity and TDS in the rainy season.

\begin{tabular}{lllllll}
\hline Sampling Point & Turbidity $(\mathbf{N T U})$ & $\mathbf{p H}$ & Dissolved $\mathbf{C O}_{\mathbf{2}}(\mathbf{g} / \mathbf{L})$ & Temperature $\left({ }^{\circ} \mathbf{C}\right)$ & Conductivity $(\boldsymbol{\mu S} / \mathbf{C m})$ & $\mathbf{T D S}(\mathbf{m g} / \mathbf{L})$ \\
\hline P1 & 130 & 3.8 & 2.65 & 16.3 & 65 & 25 \\
P2 & 290 & 3.9 & 2.50 & 15.7 & 60 & 24 \\
P3 & 2.9 & 5.25 & 1.20 & 16.3 & 130 & 77 \\
P4 & 320 & 4 & 1.98 & 15.8 & 70 & 27 \\
P5 & 50 & 6.8 & 0.50 & 16.5 & 139 & 89 \\
P6 & 4.7 & 4.78 & 1.6 & 16.6 & 55 & 28 \\
\hline
\end{tabular}

Dry season

Table 2. Results of Turbidity, pH, Dissolved $\mathrm{CO}_{2}$, Temperature, conductivity and TDS in the Dry season.

\begin{tabular}{|c|c|c|c|c|c|c|}
\hline Sampling Point & Turbidity & pH & Dissolved $\mathrm{CO}_{2}(\mathrm{~g} / \mathrm{L})$ & Temperature & Conductivity & $\overline{\text { TDS }}$ \\
\hline $\mathrm{P} 1$ & 117 & 3.41 & 3.00 & 20 & 70 & 31 \\
\hline P2 & 261 & 3.56 & 2.80 & 19.9 & 65 & 30 \\
\hline P3 & 3.2 & 4.39 & 2.04 & 20 & 130 & 65 \\
\hline P4 & 224 & 4.10 & 2.55 & 19 & 66 & 34 \\
\hline P5 & 39.6 & 6.37 & 0.4 & 20.4 & 156 & 78 \\
\hline P6 & 3.3 & 4.93 & 1.50 & 20.7 & 51 & 25 \\
\hline
\end{tabular}


$\mathrm{pH}$

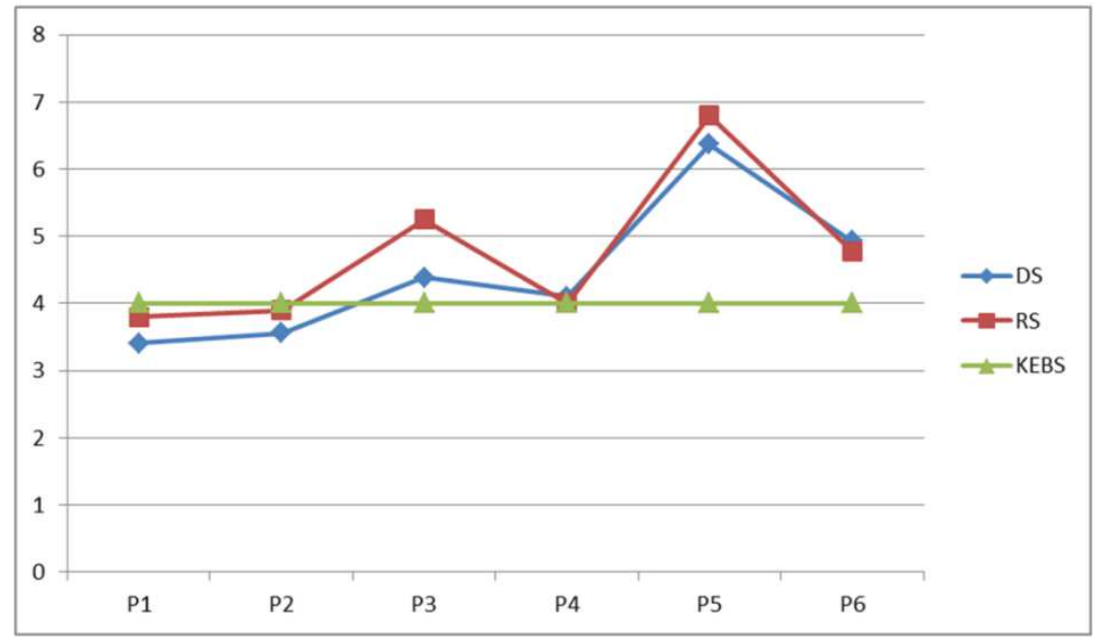

Figure 3. Plots of $p H$ values in the study area.

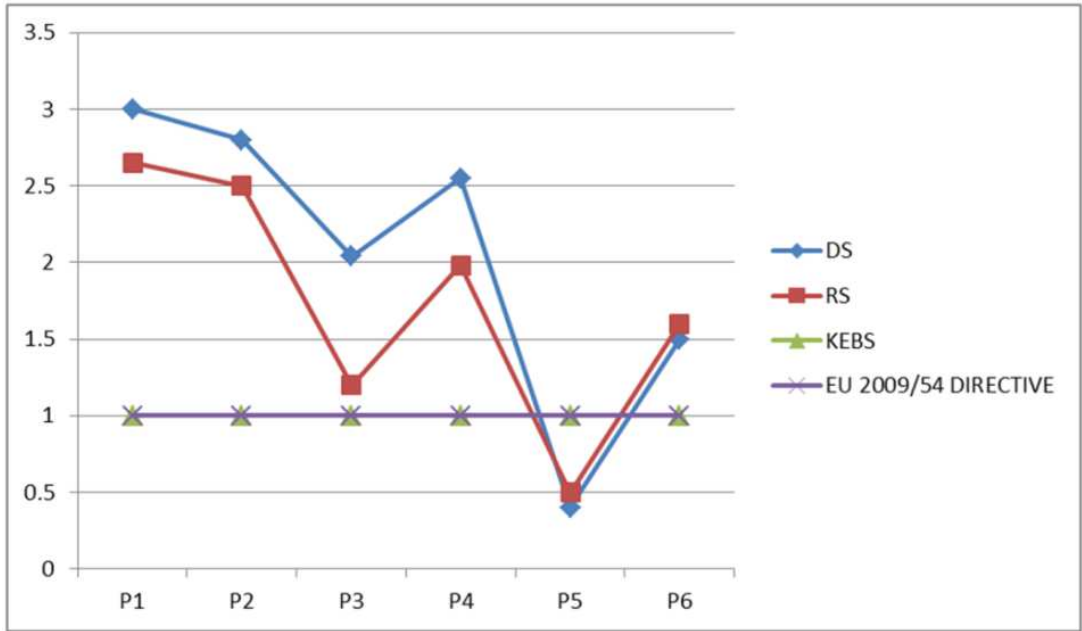

Figure 4. Plot of $\mathrm{CO}_{2}$ values in the study area.

\subsection{Anions}

\subsubsection{Phosphates}

The phosphates concentrations in the samples ranged from $0.56 \mathrm{mg} / \mathrm{L}$ in $\mathrm{P} 1$ and $\mathrm{P} 3$ to $0.85 \mathrm{mg} / \mathrm{L}$ in $\mathrm{P} 4$ during the dry season and between 0.4 in $\mathrm{P} 1$ and $1.3 \mathrm{mg} / \mathrm{L}$ in $\mathrm{P} 2$. Comparably all the concentration were within the KEBS and WHO guidelines for drinking water of $45 \mathrm{mg} / \mathrm{L}$. Phosphates are naturally derived from decomposition of organic matter as well as leaching of phosphorus rich agricultural inputs such as fertilizers and pesticides. Phosphates in the sampling points were attributed to agricultural activities and the decomposing organic matter especially the swamp decaying vegetation.

\subsubsection{Nitrates}

Nitrate concentrations from all the six sampling point during the dry and rainy season were all within the allowed WHO and KEBS limit of $50 \mathrm{mg} / \mathrm{L}$. Nitrate concentrations during the dry season ranged from $0.1 \mathrm{mg} / \mathrm{L}$ in $\mathrm{P} 4$ to $5.1 \mathrm{mg} / \mathrm{L}$ in $\mathrm{P} 3$. The nitrate presences in water can be attributed to fertilizers leaching especially nitro-phosphorus fertilizers as well as from human and animal waste [1]. That explains why high nitrates concentrations were recorded at $\mathrm{P} 4$-the hand dug well that is located new cattle shed and a nearby pit latrine

\subsubsection{Chlorides}

The chloride concentrations were between $0.499 \mathrm{mg} / \mathrm{L}$ to $6.978 \mathrm{mg} / \mathrm{L}$ in P6 and P2 respectively in the dry season. Similarly, the chloride concentrations in the rainy season ranged from $0.200 \mathrm{mg} / \mathrm{L}$ in $\mathrm{P} 6$ to $5.936 \mathrm{mg} / \mathrm{L}$ in $\mathrm{P} 2$. These concentrations were within the allowed limits of not more than $250 \mathrm{mg} / \mathrm{L}$ permitted by KEBS for potable drinking water.

\subsubsection{Sulphate}

Low concentrations of sulphate were recorded in all sampling point. In some points the sulphate concentrations were recorded as zero indicating that sulphate were not detected during the analysis. KEBS standards for domestic drinking water sets for maximum allowed concentration of sulphate at $400 \mathrm{mg} / \mathrm{L}$. 
Dry season

Table 3. Concentration of Anions during the dry season.

\begin{tabular}{lllll}
\hline Sampling Points & Nitrate $(\mathbf{m g} / \mathbf{L})$ & Phosphate $(\mathbf{m g} / \mathbf{L})$ & Sulfate $(\mathbf{m g} / \mathbf{L})$ & Chloride $(\mathbf{m g} / \mathbf{L})$ \\
\hline P1 & 1.8 & 0.56 & 0 & 2.487 \\
P2 & 1.3 & 0.81 & 2 & 6.978 \\
P3 & 5.1 & 0.56 & 0 & 1.499 \\
P4 & 0.1 & 0.85 & 1 & 2.487 \\
P5 & 0.3 & 0.74 & 0 & 0.999 \\
P6 & 1.6 & 0.74 & 0 & 0.499 \\
KEBS & 50 & 45 & 400 & 250 \\
WHO & 50 & 45 & 250 & 250 \\
\hline
\end{tabular}

Rainy season

Table 4. Concentrations of Anions during the rainy season.

\begin{tabular}{lllll}
\hline Sampling Points & Nitrate $(\mathbf{m g} / \mathbf{L})$ & Phosphate $(\mathbf{m g} / \mathbf{L})$ & Sulfate $\mathbf{( m g} / \mathbf{L})$ & Chloride $(\mathbf{m g} / \mathbf{L})$ \\
\hline P1 & 1.0 & 0.40 & 1 & 4.004 \\
P2 & 0.8 & 1.30 & 1 & 5.936 \\
P3 & 6.3 & 0.60 & 0 & 1.676 \\
P4 & 0.0 & 0.96 & 1 & 3.112 \\
P5 & 0.4 & 0.88 & 1 & 1.492 \\
P6 & 1.8 & 45 & 0 & 0.200 \\
KEBS & 50 & 45 & 400 & 250 \\
WHO & 50 & 250 & 250 \\
\hline
\end{tabular}

\subsection{Cations}

\subsubsection{Iron}

The iron concentration ranged from $0.09 \mathrm{mg} / \mathrm{L}$ in $\mathrm{P} 6$ to $3.85 \mathrm{mg} / \mathrm{L}$ in $\mathrm{P} 2$ during the dry season and between 0.07 $\mathrm{mg} / \mathrm{L}$ in $\mathrm{P} 6$ to $4 \mathrm{mg} / \mathrm{L}$ in $\mathrm{P} 2$ in the rainy season. Comparably, most of these values were higher than the KEBS [5] of 0.3 $\mathrm{mg} / \mathrm{L}$ and WHO (2015) of $0.5 \mathrm{mg} / \mathrm{L}$ maximum permitted limits in drinking water. Points with concentration higher than the permitted limits included P1, P2, P4 and P5.

\subsubsection{Manganese}

Manganese concentration ranged between $0.3 \mathrm{mg} / \mathrm{L}$ in $\mathrm{P} 5$ and P6 to $1.2 \mathrm{mg} / \mathrm{L}$ in $\mathrm{P} 4$ during the rainy season and between 0.3 $\mathrm{mg} / \mathrm{L}$ in $\mathrm{P} 6$ to $1.0 \mathrm{mg} / \mathrm{L}$ during the dry season. These concentrations were higher than the maximum permitted limits of $0.1 \mathrm{mg} / \mathrm{L}$ WHO [12]. However, KEBS permits concentrations of not more than $0.5 \mathrm{mg} / \mathrm{L}$. High concentrations of both the iron and manganese were attributable to leaching of these minerals from soils and rock with higher concentration of the same.

Rainy Season

Table 5. Concentrations of Iron and manganese during the rainy season.

\begin{tabular}{lll}
\hline Sampling Point & Iron $\mathbf{( m g / L )}$ & Manganese (mg/L) \\
\hline P1 & 3.02 & 0.8 \\
P2 & 4.0 & 0.8 \\
P3 & 0.17 & 0.8 \\
P4 & 1.2 & 1.2 \\
P5 & 1.36 & 0.3 \\
P6 & 0.07 & 0.3 \\
KEBS & 0.3 & 0.5 \\
WHO & 0.5 & 0.1 \\
\hline
\end{tabular}

Dry Season

Table 6. Concentrations of Iron and manganese during the dry season.

\begin{tabular}{lll}
\hline Sampling Point & Iron $(\mathbf{m g} / \mathbf{L})$ & Manganese $(\mathbf{m g} / \mathbf{L})$ \\
\hline P1 & 2.43 & 1.0 \\
P2 & 3.85 & 0.6 \\
P3 & 0.19 & 0.8 \\
P4 & 0.71 & 0.9 \\
P5 & 0.77 & 0.4 \\
P6 & 0.09 & 0.3 \\
KEBS & 0.3 & 0.5 \\
WHO & 0.5 & 0.1 \\
\hline
\end{tabular}


Manganese

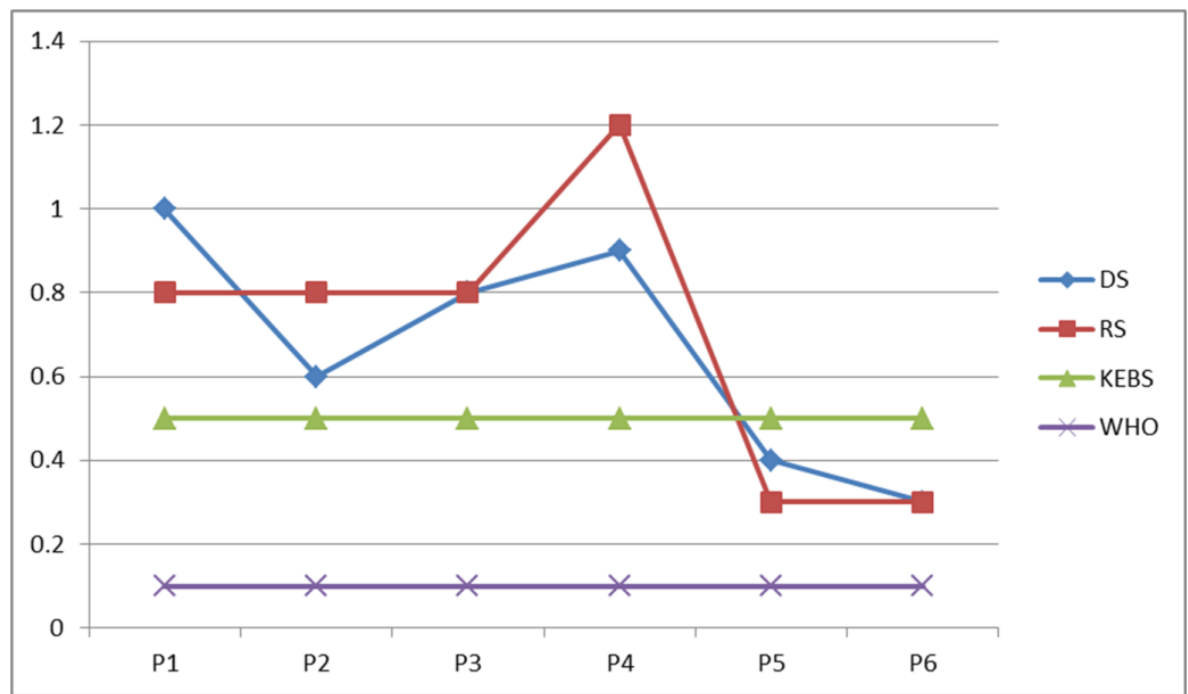

Figure 5. A graphical comparison of Manganese concentration (ppm) during the rainy (RS) and dry (DS) seasons with KEBS and WHO set standards.

Iron

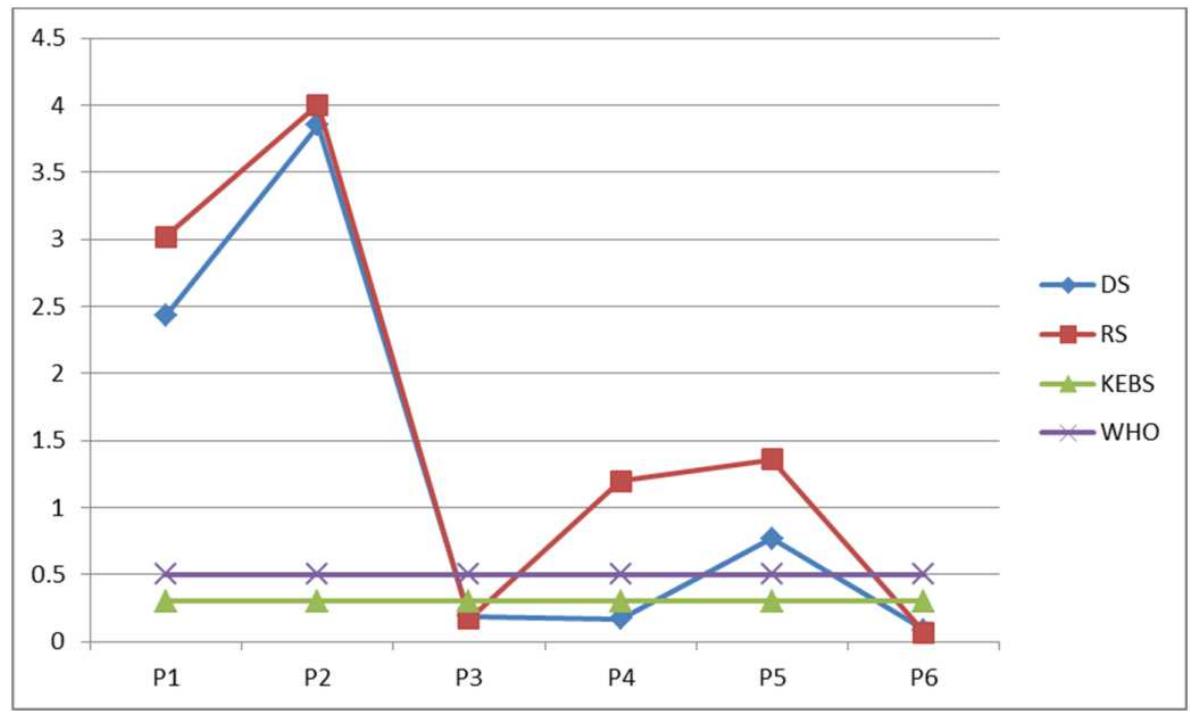

Figure 6. A graphical comparison of Iron concentration (ppm) during the rainy (RS) and dry (DS) seasons with KEBS and WHO set standards.

\section{Conclusion and Recommendations}

This research aimed to determine the water quality of Kilibwoni bubbling spring water and ascertain whether this water could be used as naturally carbonated mineral water. The study was to establish whether the water quality parameters were within the WHO [12] and KEBS drinking water standards. The research findings are in accord with the set hypothesis that Kilibwoni spring water can be used as natural mineral water (carbonated water). However, some purification is needed to remove microbial contaminants and to lower the Turbidity of the water.

The samples collected from Kilibwoni bubbling spring water met the WHO [12] and KEBS requirements for nitrates, chlorides, phosphates, sulfates, total water hardness as well as for sodium and potassium. However, higher values than those required by WHO and KEBS were recorded for both manganese and iron in all the point sampled except for P3 and P6 that recorded values conforming to the required standard, P5 and P6 also recorded values higher than those recommended by WHO, although they conformed to the local KEBS standards this may be attributed to soils and rocks that are highly rich in these mineral being present in the area of study.

All the points sampled had water contaminated with both total and faecal coliforms. The presence of these bacteria is attributable to human activities, including livestock grazing activities around the area and human waste spillage or seeping into the water, especially at P3 a hand bug well that is located not far from the pit latrine. 
Water is classified as naturally carbonated water if the water is carbonated from the source. The carbon dioxide dissolved in the water is believed to have emanated geological activities underground. According to the 2009/54/EC Directive of the European Commission and the KEBS [5], water is naturally carbonated if it contains more than $1 \mathrm{~g} / \mathrm{L}$ of dissolved carbon dioxide and a $\mathrm{pH}$ minimum of 4. All samples except P5 recorded dissolved $\mathrm{CO}_{2}$ above $1 \mathrm{~g} / \mathrm{L}$. However, P1 and P2 recorded $\mathrm{pH}$ values of less than 4, i.e 3.8 and 3.9 for $\mathrm{P} 1$ and $\mathrm{P} 2$ during the rainy season, and 3.41 and 3.56 respectively during the dry season. In conclusion, therefore, the water samples collected from this area qualify to be used as naturally carbonated water except for the P5 sample (sample collected from the river). However, the $\mathrm{pH}$ for $\mathrm{P} 1$ and $\mathrm{P} 2$ needs to be adjusted to at least 4 .

The water from all the sampling points was highly turbid and didn't meet the WHO and the KEBS standards except P6, and P3 which recorded values of below 5.0 NTU. Besides, all except for P5 samples that recorded $\mathrm{pH}$ values of 6.8 and 6.37 during the rainy and the dry season were highly acidic, recording $\mathrm{pH}$ values below 5.25.

The area where these bubbling springs are located should be fenced off. This will help preserve the spring and minimize microbial contamination of the waters

The water should be harnessed, purified to reduce the turbidity and the microbial contamination and the $\mathrm{pH}$ adjusted to above 4 before being used as naturally carbonated water

The water is as well rich in iron and can be used as iron supplement water, to deal with iron deficiency complications

\section{References}

[1] Abdelwaheb M, Jebali K, Dhaouadi H, Dridi-Dhaouadi S., (2019). Adsorption of nitrate, phosphate, nickel and lead on soils: Risk of groundwater contamination. Ecotoxicology and Environmental Safety, 179: 182-187 doi: 10.1016/j.ecoenv.2019.04.040.

[2] Bisweswar G., Al-Hamairi A., \& Jin S., (2020). Carbonated water Injection: An efficient EOR Approach. A Review of Fundamentals and Prospects. Journal of Petroleum and Production Technology 10: 673-685 https://doi.org/10.1007/s13202-019-0738-2

[3] Directive 2009/54/EC of the European Parliament and Council
(June, $18^{\text {th }}$ 2009). Exploitation and Marketing of Natural Mineral Waters. Official Journal of the European Union, $L$ $164,45-58$.

[4] Kipkorir E C. (2016) Environmental Impact Assessment and Audit, University of Eldoret, Unpublished Report.

[5] KEBS 2015 KS05-459-1, Drinking Water. Specification Part 1; the Requirements for Drinking Water (ICS 13.060.20), third ed., KBS, Nairobi, 2007.

[6] Michou E., Mastan A., Ahmed S., Mistry S., \& Hamdy S., (2012). Examining the Role of Carbonation and Temperature on ater Sallowing Performance: A Swallowing Reaction Time Study. Chem Senses. 37 (9): 799-807 DOI: 10.1093/chemse/bjs061.

[7] Nandi County Integrated Development plan (CIDP)(2013), County Government of Nandi.

[8] Schoppen, S., Pérez-Granados, A. M., Carbajal, A., Oubiña, P., Sánchez-Muniz, F. J., Gómez-Gerique, J. A., \& Vaquero, M. P. (2004). A sodium-rich carbonated mineral water reduces cardiovascular risk in postmenopausal women. The Journal of nutrition, 134 (5), 1058-1063.

[9] Rostami B., Mohammadifar M., Pourafshary P., \& Khosravi M., (2017). Impact of Pure $\mathrm{CO}_{2}$ and Carbonated Water Injection to Enhance Recovery of Heavy Oil. Journal of Petroleum and Environmental Biotechnology, 8 (4) DOI: 10.4172/2157-7463-C1-034.

[10] Statista. (2018). "Bottled Water." Statista. Retrieved from https://www.statista.com/outlook/20010000/102/bottledwater/europe

[11] Steen, D., \& Ashurst, P. R. (Eds.). (2008). Carbonated soft drinks: formulation and manufacture. John Wiley \& Sons.

[12] The World Health Organization (WHO). (2017). Guidelines for drinking-water quality, 4th edition, incorporating the $1 \mathrm{st}$ addendum. Retrieved from: https://www.who.int/publications/i/item/9789241549950

[13] Toxqui L., \&Vaquero M. P., (2016). An Intervention with Mineral Water Decreases Cardiometabolic Risk Biomarkers. A Crossover, Randomised, Controlled Trial with Two with Two Mineral Waters in Moderately Hypercholesterolaemic Adults. Nutrients 8 (7), 400 https://doi.org/10.3390/nu8070400

[14] Morishita M., Mori S., Yamagami S., \& Mizutani M., (2014). Effect of Carbonated Beverages on Pharyngeal Swallowing in Young Individuals and Elderly Inpatients. Dysphagia: (2): 213-22. doi: 10.1007/s00455-013-9493-6. 